\title{
Water Buffaloes grazing behaviour at the Lake Kerkini National Park, Northern Greece
}

\author{
Eleni T. Tsiobani ${ }^{1}$, Maria D. Yiakoulaki ${ }^{2 *}$, Nikolaos D. Hasanagas ${ }^{3}$, \\ Georgios Menexes ${ }^{1}$ \& Konstantinos Papanikolaou ${ }^{1}$
}

Key words: Bubalus bubalis, grazing activities, grasslands, social behaviour.

Ključne besede: Bubalus bubalis, paša, travišče, pašno vedenje, socialno vedenje.

Received: 16. 12. 2015

Revision received: 3. 4. 2016

Accepted: 15. 4. 2016

Co-ordinating Editor:

Orsolya Valkó

\begin{abstract}
The monthly variation of Greek water buffaloes' grazing behaviour was investigated at the Lake Kerkini National Park in Greece. Direct observations were carried out on six female buffaloes for two consecutive days every month for a one-year period, and the time spent (in minutes) on their grazing-related activities (feeding, moving, wallowing, standing, ruminating, drinking, and lying) was recorded. Moreover, social and aggressive interactions and selfgrooming were recorded as number of events. Also, the daily distance travelled by buffaloes was recorded with a handheld GPS. Buffaloes travelled on average $6.9 \mathrm{~km} /$ day, and they walked their longest distance in June $(10.7 \mathrm{~km} /$ day $)$ and their shortest in September $(2.9 \mathrm{~km} /$ day $)$. They spent more time $(\mathrm{P}<0.05)$ on feeding (309.2 $\mathrm{min} /$ day) compared to moving (121.7 min/day), wallowing (27.9 $\mathrm{min} /$ day $)$, standing $(20.2 \mathrm{~min} /$ day $)$, ruminating $(15.4 \mathrm{~min} /$ day $)$, drinking ( $4.7 \mathrm{~min} /$ day) and lying ( $4.2 \mathrm{~min} /$ day). Greek water buffaloes seem to be sociable rather than aggressive animals as they devote to these activities on average 18.2 vs 0.5 events/day. We can conclude that the animals adjust their grazing behaviour to climatic conditions and the availability of forage resources.
\end{abstract}

\section{Izvleček}

Proučevali smo mesečno spreminjanje vedenja vodnih bivolov pri paši v narodnem parku Jezero Kerkini v severni Grčiji med novembrom leta 2011 in decembrom leta 2012. Neposredno smo opazovali šest samic vodnih bivolov dva zaporedna dneva vsak mesec v letu. Zabeležili smo, koliko časa v minutah porabijo za dejavnosti, povezane $s$ pašo (hranjenje, premikanje, valjanje, stanje, prežvekovanje, pitje in ležanje). Dodatno smo kot število dogodkov zabeležili še druge aktivnosti: socialno in agresivno medsebojno delovanje, samonegovanje. Z GPS napravo smo beležili dnevne razdalje vodnih bivolov. Povprečno so prehodili $6,9 \mathrm{~km}$ na dan, najdaljšo razdaljo so naredili junija $(10.7 \mathrm{~km} / \mathrm{dan})$ in najkrajšo septembra $(2,9 \mathrm{~km} / \mathrm{dan})$. Bivoli so porabili $(\mathrm{P}<0,05)$ več časa za hranjenje $(309,2 \mathrm{~min} / \mathrm{dan})$ kot za gibanje $(121,7 \mathrm{~min} / \mathrm{dan})$, valjanje $(27,9 \mathrm{~min} / \mathrm{dan})$, stanje $(20,2 \mathrm{~min} / \mathrm{dan})$, prežvekovanje (15,4 $\mathrm{min} / \mathrm{dan})$, pitje (4,7 $\mathrm{min} / \mathrm{dan})$ in ležanje (4,2 $\mathrm{min} / \mathrm{dan})$. Grški vodni bivoli so bolj socialne kot agresivne živali, saj je socialnih aktivnosti več kot agresivnih (18,2 proti 0,5$)$. Zaključimo lahko, da živali prilagodijo svoje vedenje, povezano s pašo, klimatskim razmeram in količini paše, ki je na voljo.

\footnotetext{
1 Department of Animal Science, Faculty of Agriculture, Forestry and Natural Environment, Aristotle University of Thessaloniki, 54124 Thessaloniki, Greece

2 Department of Range Science (236), Faculty of Agriculture, Forestry and Natural Environment, Aristotle University of Thessaloniki, 54124 Thessaloniki, Greece

3 University Forest Administration, Aristotle University of Thessaloniki, 54124 Thessaloniki, Greece

* Corresponding author: Maria Yiakoulaki, E-mail address: yiak@for.auth.gr
} 


\section{Introduction}

Low intensity farming systems and traditionally managed pastures are of crucial importance for biodiversity conservation in Europe (Dengler et al. 2014, Sutcliffe et al. 2015). Traditional grazing by local breeds should be considered as one of the most adequate options to achieve a proper management of biodiversity and related ecosystem services in grasslands (Török et al. 2014, Jerrentrup et al. 2015). Most information concerning low intensity grazing systems are provided in relation to cattle and/or sheep grazing (Metera et al. 2010, Jerrentrup et al. 2015, Török et al. 2016), while information on other types of grazing animals, such as Mediterranean river buffaloes, are rather scarce (but see Napolitano et al. 2007).

Water buffaloes (Bubalus bubalis) have been an integral part of Greek livestock farming since the end of the $19^{\text {th }}$ century. These animals are considered as the last representatives of the Mediterranean sub-type of the River buffalo, which have developed some unique morphological and performance characteristics due to their geographic isolation for many years (Georgoudis et al. 1998). They are called Greek water buffaloes as the buffaloes of the European countries are known by the name of the country in which they are raised (Cockrill 1977).

The total population of Greek water buffaloes has dramatically declined from 70000 animals counted at the end of 1950s (National Statistical Service of Greece 1960) to 3128 (Greek Buffalo Breeders Livestock Cooperative 2011). For this reason, they are characterised as an endangered-maintained local breed (FAO 2007). Nowadays, water buffaloes are mainly distributed in the northern, central and western part of the country. However, the majority of them ( 2520 heads $-80 \%$ of their population) is concentrated around the Lake Kerkini National Park in Northern Greece.

Traditionally, the buffalo farming system has been practised extensively, based on grazing of natural grasslands for 6-7 months. To counterbalance the feed gap, farmers utilise complementary forage resources, such as forage crops (alfalfa, barley, wheat, rye and oats) and crop residues (maize, wheat, barley and sunflower) after harvesting. They also utilise purchased feedstuffs, mainly roughages and concentrates, during the entire period of the year in order to improve animal performance (Tsiobani et al. 2013). Herds are pure, and they are permanently herded. The role of the herder is to lead the animals to grazing lands, to hinder them from entering privately-owned cultivated areas and to ensure their return to the stable in the evening.

Research concerning the water buffaloes in Europe has mainly focused on productive characteristics (Buffoni et al. 2011), genetic improvement (Moioli et al. 2001) and the impact of their grazing on wetlands (Georgoudis et al. 1998, Kazoglu \& Papanastasis 2001, Wiegleb \& Krawczynski 2010). Antkowiak et al. (2012) investigated the behaviour of water buffaloes during grazing on meadows and pastures in Poland, while in a recent review, Napolitano et al. (2013) presented the behaviour and welfare of dairy water buffaloes in confinement and in extensive conditions. In general, data concerning water buffaloes' activities during grazing are very limited, and in their review, Napolitano et al. (2013) emphasised the lack of knowledge in buffaloes' social behaviour as well as in other aspects.

The aims of this study were to determine the monthly variation of: (a) the grazing routes of water buffaloes and the distances travelled, (b) the time devoted by the animals to the activities of feeding, moving, wallowing, standing, ruminating, drinking and lying during grazing and (c) their social, self-grooming and aggressive behaviour.

\section{Material And Methods}

\section{Study Area}

The research was conducted at Limnochori (longtitude $23^{\circ} 12^{\prime} 11.24^{\prime \prime E}$, latitude $41^{\circ} 12^{\prime} 19.23^{\prime \prime} \mathrm{N}$, altitude $41 \mathrm{~m}$ asl) located at the Lake Kerkini National Park in Northern Greece from November 2011 to October 2012. The Lake Kerkini is one of the ten wetlands in Greece of international importance, protected by the Ramsar Convention. Limnochori is a common rural lowland village lying at the east side of the Lake.

The climate of the area is characterised by hot dry summers and cold wet winters. During the study period, the hottest months were July $\left(30.2^{\circ} \mathrm{C}\right)$ and August $\left(28.3^{\circ} \mathrm{C}\right)$, while the coldest ones were January $\left(3.8^{\circ} \mathrm{C}\right)$ and February $\left(4.7^{\circ} \mathrm{C}\right.$ ). The total rainfall surpassed $570 \mathrm{~mm}$ (Lake Kerkini Management Authority 2012).

Vegetation of grasslands consists mainly of herbaceous species, e.g. Sorghum halepense, Phragmites australis, Festuca arundinacea, Chrysopogon gryllus, Bromus hordeaceus, Cynodon dactylon, Trifolium subterraneum, Trifolium repens, Cichorium intybus, Cerastium arvense, Taraxacum officinale, Minuartia verna and Cirsium arvense. Woody species such as Rubus spp., Clematis vitalba, Sambucus nigra, Genista cardinalis, Phillyrea latifolia etc. are also present. Forage crops include alfalfa, barley, wheat, rye and oats, while crop residues comprise maize, wheat, barley, sunflower and beetroot. 
The study area was heavily grazed (2.15 AU/ha/year) by livestock (buffaloes, cattle and small ruminants) as reported by Yiakoulaki et al. (2015). The intensity of livestock grazing highly influences the impact on grasslands (Papanastasis et al. 1998, Török et al. 2014, 2016). Long-term heavy grazing of water buffaloes in the study area may have affected the cover and the botanical composition of grasslands, but to our knowledge, there is no published evidence for this. Water buffaloes are considered grazers rather than browsers, and they usually select a wider range of plant species compared to cattle (Napolitano et al. 2013). Tall grasses such as Sorghum halepense, Festuca arundinacea and Phragmites australis as well as the annual leaves and shoots of Quercus coccifera, Sambucus nigra and Phillyrea latifolia are highly preferred by them according to Tsiobani et al. (2014). The selective grazing of water buffaloes may suppress the growth of tall grasses and affect the shape and the height of woody species.

\section{Animals and Management Facilities}

In the study area, the average size of grazing buffalo herds was 185 animals according to the Greek Buffalo Breeders Livestock Cooperative (2011). The herds consisted mainly of females, while a few males co-existed only for reproduction purposes. A herd of 40 Greek water buffaloes was used for the purposes of this study. The male animals weighed $575 \mathrm{~kg}$ on average, the females $475 \mathrm{~kg}$. They were raised only for meat, and their milk was exclusively left for suckling calves. The stable was placed just beside the Lake Kerkini, and it was protected by an electric fence. The animals had free access to water and trace mineralised salt blocks. Supplements were not provided to them four days before as well as during the observation days so that their grazing behaviour was not affected.

\section{Data Collection and Analysis}

A focal sampling technique (Altman 1974) was applied to six adult (four years old) female buffaloes, which were marked with large numbers on their sides for identification. During the 12-month study period, the animals were followed continuously by two observers for two consecutive days per month. They were observed from an approximate distance of 3-4 $\mathrm{m}$ in order not to be disturbed during grazing.

The observers were equipped with stop watches and one-hour observation protocol forms, which were divided into six observation periods of 10 minutes each. The six experimental animals were observed in sequence during the observation hour (one 10-minute observation period per hour and animal), and their grazing-related activities were recorded every 15 seconds. Grazing-related activities were defined as follows: feeding (grazing or browsing while walking or standing), moving (walking or running without grazing), wallowing (time spent in the water of the Lake or in mudholes), standing (the time that animals ceased all their activities and stood inactive), ruminating (time spent on rumination), drinking (time spent on drinking) and lying (sitting without feeding or ruminating). In addition, during each 10-minute observation period, other activities such as social interactions (nursing, sniffing, licking and nuzzling conspecifics), self-grooming (scratching on a tree or itself) and aggressive interactions (pushing, butting and threatening conspecifics) were recorded as number of events. The observation hours varied among months. For each grazing day, there were six to eleven observation hours. The total daily duration was 6 hours in autumn, 11 in summer, 7 in winter and 9 in spring. A total of 1212 10-minute individual recordings were obtained.

During the first observation day of each month, the track of the herd was recorded every ten minutes by an observer who used a handheld Global Positioning System device (Garmin e-Trex Vista; Garmin, Schaffhausen, Switzerland). The tracks were imported into ArcGIS desktop 10.0 (Esri, Redlands, CA, USA), and segments of 10-minute sampling intervals were detected. Each segment was overlaid with a detailed land use map, which was derived from IKONOS images (acquisition date November 2007). The result was the herd's linear route and the distance travelled each month. For easier understanding, the routes were highlighted in different colours.

Data were analysed using the ANOVA method according to a linear model involving three factors within animals with repeated measures (Girden 1992): factor "month" with 12 levels, factor "day" with two levels and factor "activities" with seven levels for the grazing-related activities data and three levels for the other activities data. Within a given day, different animals served as replications. The Least Significant Difference (LSD) criterion was used for means comparison. Tabulated data for grazing-related activities were presented as average minutes per day. Prior to ANOVA, other activities data (number of events) were transformed to square roots in order to achieve normality and homogeneity of error variances; mean values were back-transformed. In all hypothesis-testing procedures, the significance level was set at $\mathrm{P}<0.05$. All statistical analyses were performed with SPSS v.20 software (SPSS Inc., Ill: Chicago, USA). 


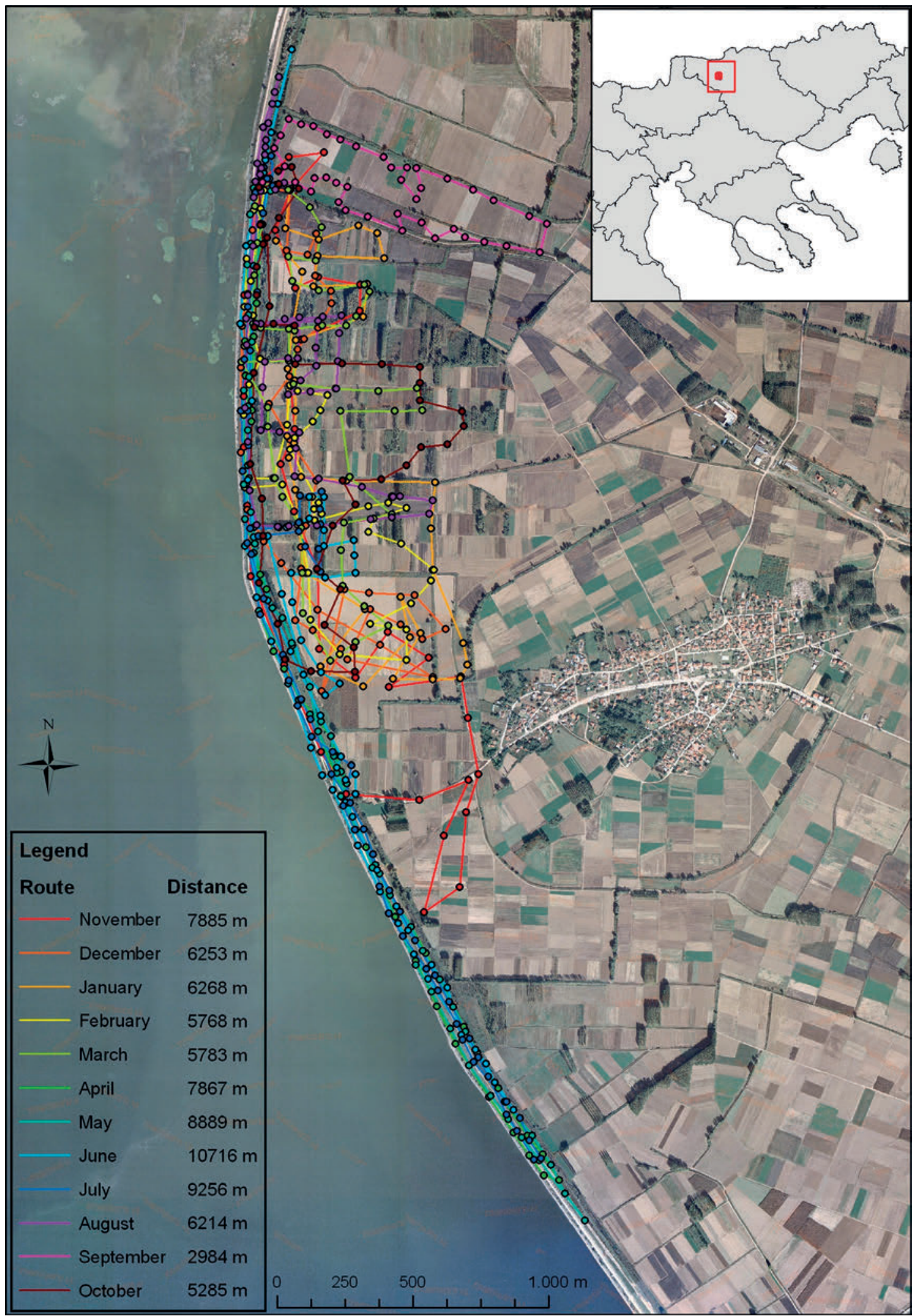

Figure 1: Monthly grazing routes and distances travelled by water buffaloes at the Lake Kerkini National Park in Northern Greece. Slika 1: Mesečne poti in razdalje, ki so jih prepotovali vodni bivoli med pašo v narodnem parku Jezero Kerkini v severni Grčiji. 


\section{Results}

\section{Routes and Distances Travelled by Buffaloes}

The routes travelled by buffaloes throughout the year are shown in Figure 1. The average distance travelled daily by buffaloes was $6.9 \mathrm{~km}$. The longest distance was recorded in June $(10.7 \mathrm{~km} /$ day $)$, the shortest in September $(2.9$ $\mathrm{km} /$ day). Grasslands were located along the lakeside, where buffaloes grazed from May to July. During the remaining months of the year (August to April), buffaloes also grazed on agricultural land (forage crops and crop residues).

\section{Buffaloes' grazing-Related Activities}

The ANOVA showed that the main effect of the factors "activity" and "month" was statistically significant $(\mathrm{P}<0.001$ for both effects). The interaction effect between the factors "activity" and "month" was also statistically significant $(\mathrm{P}<0.001)$. The main effect of the factor "day" and its interaction with the factors "month" and "activity" were not statistically significant $(P>0.05)$. Feeding was the predominant grazing-related activity $(\mathrm{P}<0.05)$ of buffaloes, followed by moving, wallowing, standing, ruminating, drinking and lying (Table 1). Moving was also significantly different $(\mathrm{P}<0.05)$ from all the other activities, while no significant differences $(P>0.05)$ were found between wallowing and standing as well as drinking and lying. Ruminating was significantly different $(\mathrm{P}<0.05)$ from all the other activities except standing.

Monthly variations of time spent by buffaloes were found for all grazing-related activities. Buffaloes spent more time on feeding $(\mathrm{P}<0.05)$ in May than all the other months (Figure 2a). The shortest duration of feeding $(\mathrm{P}<0.05)$ was observed in November. They devoted more time $(\mathrm{P}<0.05)$ on moving in November, July and August compared to the other months, but there were no significant differences $(P>0.05)$ among them (Figure $2 b)$. The duration of wallowing was longer during the summer months (June, July and August); however, no significant differences $(P>0.05)$ were observed among them. Shorter durations of wallowing were observed during March, April, September and October, with no significant differences among them $(\mathrm{P}>0.05)$. Buffaloes did not wallow at all from November to February (Figure 2c). Concerning the activity of standing, higher values $(\mathrm{P}<0.05)$ appeared during July, August and October, lower ones during De-
Table 1: Mean values \pm s.e. (standard error) of buffaloes' grazing-related activities and other activities per day at the National Park of the Lake Kerkini, Northern Greece.

Tabela 1: Povprečne vrednosti \pm s.e. (standardna napaka) aktivnosti vodnih bivolov povezanih s pašo in drugih dejavnosti na dan v narodnem parku Jezero Kerkini, severna Grčija.

\begin{tabular}{|c|c|c|}
\hline$\overline{\mathrm{g}}$ & Feeding ${ }^{1}$ & $309.19^{\mathrm{a}^{*}} \pm 19.04$ \\
\hline$\stackrel{2}{2}$ & Moving ${ }^{1}$ & $121.69^{\mathrm{b}} \pm 6.41$ \\
\hline$\stackrel{b}{=}$ & Wallowing ${ }^{1}$ & $27.96 c \pm 8.92$ \\
\hline 耉 & Standing $^{1}$ & $20.21 c^{d} \pm 3.90$ \\
\hline 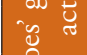 & Ruminating $^{1}$ & $15.44^{\mathrm{d}} \pm 4.15$ \\
\hline$\frac{\vec{J}}{\mathbb{H}}$ & Drinking $^{1}$ & $4.72^{\mathrm{e}} \pm 0.93$ \\
\hline صี & Lying $^{1}$ & $4.23^{\mathrm{e}} \pm 4.20$ \\
\hline 岂 & Social interactions ${ }^{2}$ & $12.08 \pm 1.8 \quad\left(3.32^{\mathrm{A}}\right)$ \\
\hline 㺃 & Self-grooming ${ }^{2}$ & $6.08 \pm 1.13\left(2.20^{\mathrm{B}}\right)$ \\
\hline$\underset{\oplus}{\mathscr{\Xi}}$ & Aggressive interactions ${ }^{2}$ & $0.54 \pm 0.18\left(0.38^{\mathrm{C}}\right)$ \\
\hline
\end{tabular}

*For each group of activities, mean values followed by different superscripted letters are statistically significantly different at $\mathrm{P}<0.05$, according to the LSD criterion (LSD $=8.40$ for grazing-related activities and LSD $=0.43$ for the transformed data of other activities).

${ }^{1}$ Buffaloes' grazing-related activities are presented in minutes/day.

${ }^{2}$ Buffaloes' other activities are presented as number of events/day. The mean values of the square root transformed data are presented and compared in parentheses.

cember, February and March. No significant differences $(\mathrm{P}>0.05)$ were detected for this activity during November, January, April, May, June and September compared to the other months (Figure 2d). The highest values of buffaloes' rumination appeared in June and July; they were significantly different $(\mathrm{P}<0.05)$ from those in November, January, March, April and May. The lowest duration of this activity appeared in March, while no rumination was observed during December and February (Figure 2e). Concerning the activity of drinking, no monthly variations $(\mathrm{P}>0.05)$ were detected. The highest value of this activity was observed in July $(\mathrm{P}<0.05)$, the lowest in December (Figure 2f). As far as lying is concerned, it was not observed during November, March and May (Figure 2g), while for the rest of the months, no statistically significant differences were detected $(P>0.05)$.

\section{Buffaloes' Other Activities}

The ANOVA showed that the main effect of the factors "activity" and "month" was statistically significant $(\mathrm{P}<0.001$ and $\mathrm{P}<0.05$, respectively). The interaction ef- 
(a) Feeding $\quad L S D 0.05=29.1$

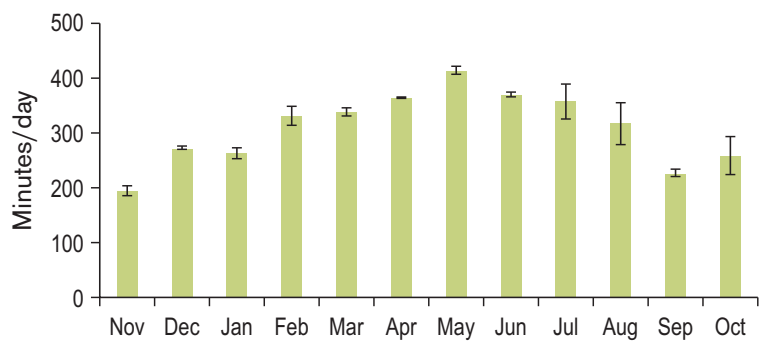

(c) Wallowing

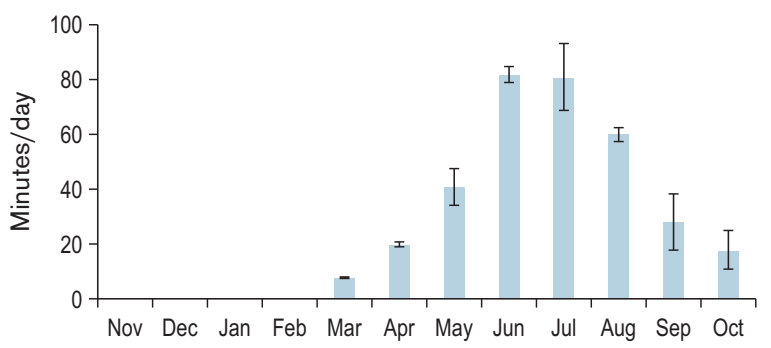

(e) Ruminating $\quad \mathrm{LSD} 0.05=29.1$

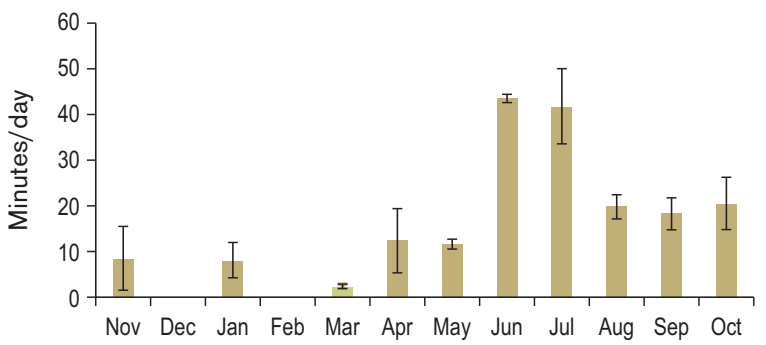

(b) Moving

$\mathrm{LSD} 0.05=29.1$ (d) Standing

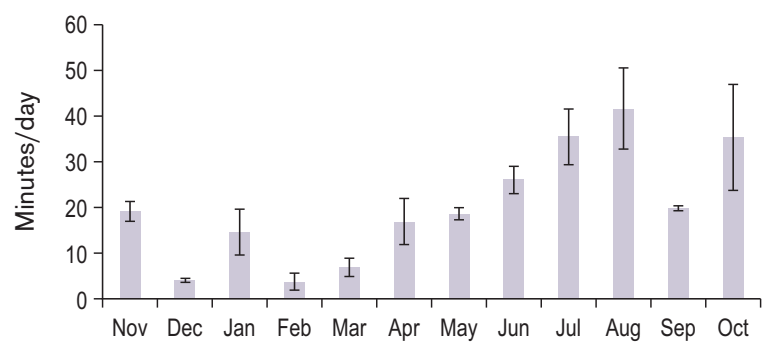

(f) Drinking

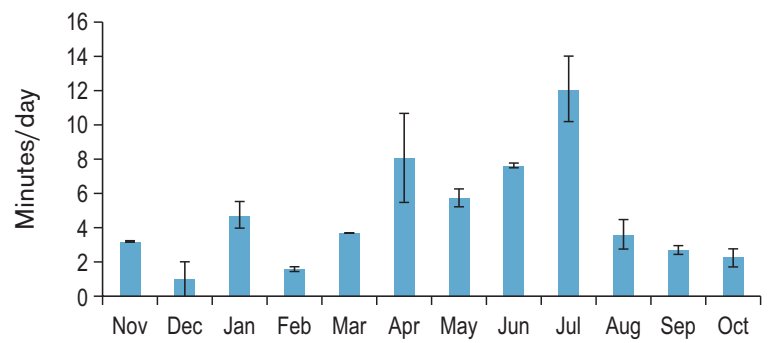

(g) Lying $\quad L S D 0.05=29.1$

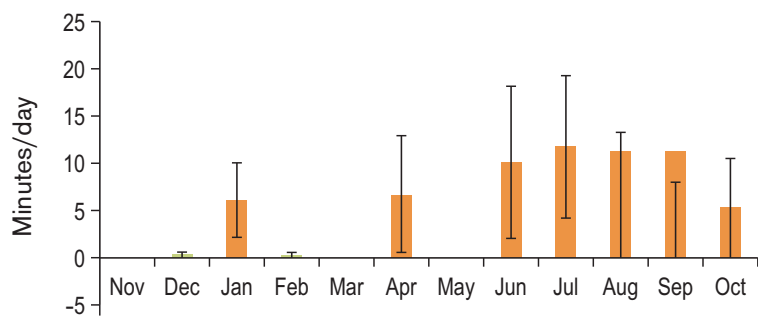

Figure 2: Monthly variation of water buffaloes' grazing-related activities (mean values, min/day) at the Lake Kerkini National Park in Northern Greece: (a) feeding, (b) moving, (c) wallowing, (d) standing, (e) ruminating, (f) drinking, (g) lying. Vertical bars represent the corresponding standard errors of means.

Slika 2: Mesečna spremenljivost aktivnosti vodnih bivolov, povezanih s pašo (povprečne vrednosti, min/dan) v narodnem parku Jezero Kerkini v severni Grčiji: (a) hranjenje, (b) gibanje, (c) valjanje, (d) stanje, (e) prežvekovanje, (f) pitje, (g) ležanje. Stolpci predstavljajo standardno napako povprečja. 
fect between the factors "activity" and "month" was also statistically significant $(\mathrm{P}<0.05)$. The main effect of the factor "day" and its interaction with the factors "month" and "activity" were not statistically significant $(\mathrm{P}>0.05)$.

Social interactions were the main other activities of buffaloes, followed by self-grooming and aggressive interactions (Table 1). Statistically significant differences $(\mathrm{P}<0.05)$ were found among these activities. According to the data presented in Table 2 (see also Figure 3), so-

Table 2: Monthly mean values of the square root transformed buffaloes' other activities data (events per day) at the National Park of the Lake Kerkini, Northern Greece.

Tabela 2: Povprečne mesečne aktivnosti bivolov (korenjeno število dogodkov na dan) v narodnem parku Jezero Kerkini, severna Grčija.

\begin{tabular}{llll} 
Month & $\begin{array}{l}\text { Social } \\
\text { interactions* }\end{array}$ & $\begin{array}{l}\text { Self- } \\
\text { grooming* }\end{array}$ & $\begin{array}{l}\text { Aggressive } \\
\text { interactions* }\end{array}$ \\
November & $3.94^{\mathrm{abc}}$ & $1.62^{\mathrm{bc}}$ & 0.87 \\
December & $1.71^{\mathrm{e}}$ & $0.50^{\mathrm{cd}}$ & 0.50 \\
January & $2.67^{\mathrm{cde}}$ & $2.85^{\mathrm{ab}}$ & 0.50 \\
February & $2.09^{\mathrm{de}}$ & $2.70^{\mathrm{ab}}$ & 0.50 \\
March & $2.72^{\mathrm{cde}}$ & $2.90^{\mathrm{ab}}$ & 0.00 \\
April & $3.41^{\mathrm{bcd}}$ & $3.73^{\mathrm{a}}$ & 0.00 \\
May & $3.81^{\mathrm{abc}}$ & $2.62^{\mathrm{ab}}$ & 0.71 \\
June & $3.60^{\mathrm{abc}}$ & $2.88^{\mathrm{ab}}$ & 0.50 \\
July & $3.32^{\mathrm{bcd}}$ & $2.28^{\mathrm{ab}}$ & 1.00 \\
August & $4.28^{\mathrm{ab}}$ & $2.62^{\mathrm{ab}}$ & 0.00 \\
September & $3.37^{\mathrm{bcd}}$ & $0.00^{\mathrm{d}}$ & 0.00 \\
October & $4.98^{\mathrm{a}}$ & $1.73^{\mathrm{bc}}$ & 0.00 \\
\hline LSD $_{0.05}$ & 1.49 & & \\
\hline
\end{tabular}

* For each other activity, mean values followed by different superscripted letters are statistically significantly different at $\mathrm{P}<0.05$, according to the Least Significant Difference (LSD) criterion.

\section{Buffaloes' other activities}

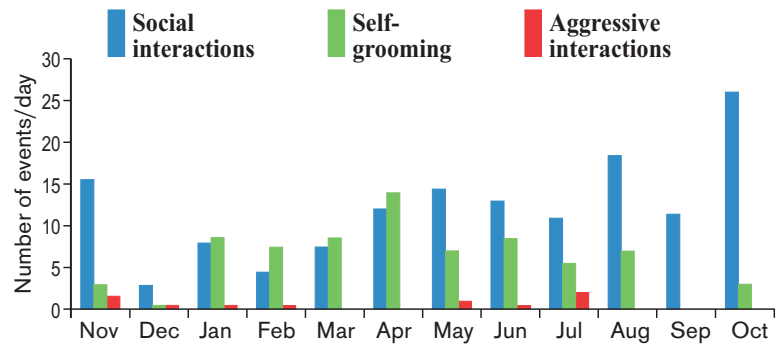

Figure 3: Monthly variation of water buffaloes' other activities (social interactions, self-grooming and aggressive interactions) expressed as number of events/day.

Slika 3: Mesečna spremenljivost drugih aktivnosti vodnih bivolov (socialni odnosi, samo negovanje in agresivni odnosi) v številu dogodkov na dan. cial interactions were statistically significantly higher $(\mathrm{P}<0.05)$ in October than in all other months except November, May, June and August. The lowest value of social interactions was recorded in December. This value was significantly different from all other months except January, February and March $(\mathrm{P}<0.05)$. The highest value of self-grooming was recorded during April, and it was significantly different $(\mathrm{P}<0.05)$ compared to October, November and December. The lowest value of this activity was observed in December, while no self-grooming was recorded in September. Regarding aggressive interactions, no monthly variations were detected $(\mathrm{P}<0.05)$.

\section{Discussion}

Research concerning water buffaloes in Europe mainly focused on other aspects (Buffoni et al. 2011, Moioli et al. 2001, Georgoudis et al. 1998, Kazoglu \& Papanastasis 2001, Wiegleb \& Krawczynski 2010) rather than their behaviour during grazing. Specifically, data about the grazing routes and the distances travelled by water buffaloes throughout the year in order to satisfy their nutritional needs are very limited (Napolitano et al. 2007). In this regard, the cited authors reported that the distance covered by buffalo heifers grazing in a fenced Mediterranean maquis area (approximately $40 \mathrm{ha}$ ) was $2.0 \mathrm{~km} /$ day on average. They also found shorter distances travelled during summer $(1.6 \mathrm{~km} /$ day $)$ compared to spring $(2.8 \mathrm{~km} /$ day). To the contrary, we found that the buffaloes travelled $6.9 \mathrm{~km} /$ day on average, walked longer distances during June $(10.7 \mathrm{~km} /$ day $)$ and July $(9.2 \mathrm{~km} /$ day) and the shortest in September $(2.9 \mathrm{~km} /$ day $)$. The longer distances could be attributed to low forage quality and availability. In this regard, Papanastasis et al. (2008) stated that forage of herbaceous species in Greece is limited or dormant during the summer period. Due to high air temperatures, the grazing animals searched for water to drink and wallow as well as for shadow to rest and to be protected from the sun. In the present study, the shortest distance recorded in September was probably a result of parturitions, which occurred during this month, and of high availability of crop residues in the fields located near the stable. It is known that the daily grazing patterns of buffaloes and distances travelled were affected by the herder himself (Schlecht et al. 2006), who guided the animals to the optimal and accessible grazing areas according to his judgment. However, as soon as the animals approached these areas, they were left free to graze without the herder's influence (Arnon et al. 2011).

In extensive conditions, feeding was the most common activity of water buffaloes as they spend $62 \%$ of their 
grazing-related activities on it. This result is in accordance with Antkowiak et al. (2012), who found that water buffaloes grazing in Poland devoted $58.6 \%$ of their activities to feeding. Napolitano et al. (2007) and Schultz (1977) also mentioned that buffaloes spend most of their time in feeding, but they reported lower values for this activity ( $48 \%$ and $27 \%$, respectively). In our study, buffaloes spent $25 \%$ of their grazing day on the activity of moving in search of available forage resources, water and shade. Concerning this activity, Napolitano et al. (2007) reported a lower value (10\%) for the Italian buffalo heifers. However, it must be taken into account that the cited authors observed grazing animals in a restricted area of $40 \mathrm{ha}$, whereas in our study, buffaloes were grazing in the communal grasslands of the village.

The time devoted by buffaloes to moving is considered high, and this should be taken into account in the future grazing management plans, as this activity is related to animals' energy expenditure (Lin et al. 2011). In our study, buffaloes devoted less time (5\%) to the activity of wallowing in comparison with the results of Antkowiak et al. (2012), who found $13 \%$. Buffaloes devoted more time to the activity of wallowing during summer than during spring and autumn in order to cool down. This behaviour helps them to remove heat (due to limited sweat glands, buffaloes are unable to dissipate excess body heat through sweating (Hafez \& Shafei 1954)). Also, wallowing seems to have a protective effect against biting flies and other ectoparasites (BOSTID 1981). Buffaloes devoted to the activity of standing $4 \%$ of their grazing-related activities. They spent most time on this activity in July and August, when buffaloes, due to the high temperatures, sought shade under trees. Another period with noticeable standing values was observed in October, probably because the animals nursed their heifers while standing. The above results concerning this activity are in accordance with the findings of Napolitano et al. (2007), who reported that buffaloes displayed higher levels of inactivity in summer and autumn. Buffaloes spent $3 \%$ of their time on ruminating. This result is in contradiction with Napolitano et al. (2007) and Antkowiak et al. (2012), who reported higher values for this activity $(23 \%$ and $28 \%$, respectively). The low value of buffaloes' rumination observed in our study could be attributed to the normal practice of the farmers to shelter the animals in the stable during the night, where they have long time for rumination, but not for feeding. Rumination was most intensive in June and July $(6.5 \%$ and $6.1 \%$ of their grazing-related activities, respectively). During this period, the biomass of herbaceous species is of low quality (Papanastasis et al. 2008), and the animals need more time for remastication to reduce the particle size (Demment et al. 1987). Increased rumination activity was also observed during August, September and October $(3.3 \%, 4.7 \%$ and $4.6 \%$ of their time, respectively). In these months, buffaloes consumed mainly crop residues (maize, wheat, barley and sunflower), which are also feed of low nutritive value. Drinking and lying were the least-frequent grazing-related activities as buffaloes spent only $0.94 \%$ and $0.84 \%$ of their time on them, respectively. They devoted more time to the activity of drinking during summer, apparently due to higher temperatures. Ryan \& Jordaan (2005) reported that the African buffaloes devoted almost $3 \%$ of their grazing activities to drinking, with slightly higher values in the dry period than in the wet one. The high ambient temperatures in June and July also affected the activity of lying: buffaloes were exhausted by the long distances they had to travel under the sun in order to cover their nutritional needs, so they spent more time on this activity.

The findings of the present study indicate that buffaloes tend to be sociable animals rather than aggressive ones. Reinhart (1985) reported that $85 \%$ of the American buffaloes' disputes were harmless, while only $15 \%$ were really aggressive. The highest frequency of social interactions was recorded in August and October, probably due to the mating period and the entrance of the newborn buffaloes into the herd, respectively. In this regard, Napolitano et al. (2007) mentioned that seasons do not affect the number of social and aggressive interactions of the Italian buffalo heifers. However, in our study, monthly variation was not detected for the aggressive interactions only. The increased values of aggressiveness that appeared in November can be understood by the low availability of crop residues in the fields during the late autumn period. In general, the expression of aggressiveness increases with limited space allowance (de Rosa et al. 2008, Napolitano et al. 2013). However, this is not the case for extensive grazing as there are no space limitations. The higher values of self-grooming observed during April, specifically scratching on trees, can be attributed to the buffaloes' intention to mark their grazing area under conditions of forage affluence.

\section{Conclusions}

In our study, we found that feeding was the main grazingrelated activity of water buffaloes, followed by moving, wallowing, standing, ruminating, drinking and lying. Buffaloes spent a quarter of their time on the activity of moving. This finding as well as the fact that they travelled long distances throughout the year should be considered in future grazing management plans. Monthly variations of time spent by buffaloes were observed for all grazing- 
related activities, except drinking and lying. Variations were also found for social interactions and self-grooming activities during the year, except for aggressiveness, which was the least observed activity. Thus, it can be concluded that Greek water buffaloes are sociable rather than aggressive animals. The extensive grazing of this local breed has a long tradition and plays an important role in the management and conservation of grasslands. The Greek water buffaloes naturally adapted to the environment of the Lake Kerkini National Park adjust their grazing activities as well as their daily movements according to climatic conditions and the availability of forage resources. Extensive grazing of water buffaloes and grassland management can be linked with the protection of this endangeredmaintained local breed.

\section{Acknowledgments}

The research was funded by the Research Committee of Aristotle University of Thessaloniki, Thessaloniki, Greece (Contract No 89597). The authors wish to thank the owner of the water buffalo herd, Mr. Dragotenlis M., for his assistance during the study. The editing of the article by Dr. Aiko Huckauf is gratefully acknowledged.

\section{References}

Altman, J. 1974: Observational study of behavior: Sampling methods. Behaviour 49: 227-267.

Antkowiak, I., Pytlewski, J., Purczynska, A. \& Skrzypek, R. 2012: A preliminary study of the behaviour of water buffaloes (Bubalus bubalis) imported to Poland (Short Communication). Archiv Tierzucht 55: 415-419.

Arnon, A., Svoray, T. \& Ungar, E. D. 2011: The spatial dimension of pastoral herding: A case from the Northern Negev. Israel Journal of Ecology \& Evolution 57: 129-149.

BOSTID 1981: The water buffalo: new prospects for an underutilized animal. National Academy Press, Washington. Retrieved from http:// www.appropedia.org/The_Water_Buffalo_New_Prospects_for_an_ Underutilized_Animal_2(December 15, 2015).

Buffoni, J. N., Bonizzi, I., Pauciullo, A., Ramunno, L. \& Feligini, M. 2011: Characterization of the major whey proteins from milk of Mediterranean water buffalo (Bubalus bubalis). Food Chem 127: $1515-1520$.

Cockrill, R. 1977: The water buffalo. Food and Agriculture Organization of the United Nations (FAO). Animal Production and Health Series. No 4. Rome.

Demment, M. W., Laca, E. A. \& Greenwood, G. B. 1987: Intake in grazing ruminants: a conceptual framework. In: Owens, F. N. (ed.) Feed Intake by Cattle. Symposium Proceedings, Agricultural Experimental Station, Oklahoma State University. pp. 208-225.
Dengler, J., Janisová, M., Török, P. \& Wellstein, C. 2014: Biodiversity of Palaearctic grasslands: a synthesis. Agriculture, Ecosystems \& Environment 182: 1-14.

De Rosa, G., Grasso, F., Pacelli, C., Napolitano, F. \& Winckler, Ch. 2009: The welfare of dairy buffalo. Review article. Italian Journal of Animal Science 8 (1): 103-116.

FAO 2007: Food and Agriculture Organization of the United Nations. Breeds currently recorded in the Global Databank for Animal Genetic Resources. Rome, Italy, p. 155.

Georgoudis, A. G., Papanastasis, V. P. \& Boyazoglu, J. G. 1998: Use of Water Buffalo for Environmental Conservation of Waterland. In: Proceedings of the 8th World Conference on Animal Production, 30 June 1998, Seoul, Korea. pp. 1324-31.

Girden, E. 1992: ANOVA: Repeated Measures. Newbury Park. Sage Publications, $88 \mathrm{pp}$.

Greek Buffalo Breeders Livestock Cooperative 2011: Vironia, Northern Greece. (In Greek)

Hafez, E. S. E. \& Shafei, M. M. 1954: Sweating mechanism in the domestic buffalo. Nature 174: 1181-1182.

Jerrentrup, J. S., Seither, M., Petersen, U. \& Isselstein, J. 2015: Little grazer species effect on the vegetation in a rotational grazing system. Agriculture, Ecosystems \& Environment 202: 243-250.

Kazoglu, Y. \& Papanastasis, V.P. 2001: Effects of water buffalo grazing on the wet plant communities of the littoral zone of Lake Mikri Prespa (Greece). In: Gerken B., Görner M. (eds.): Neue Modelle zu Maßnahmen der Landschaftsentwicklung mit großen Pflanzenfressern. Natur- und Kulturlandschaft 4: 348-351.

Lake Kerkini Management Authority 2012: Kerkini, Serres Prefecture.

Lin, L., Dickhoefer, U., Müller, K., Wurina \& Susenbeth A. 2011: Grazing behavior of sheep at different stocking rates in the Inner Mongolian steppe, China. Applied Animal Behaviour Science 129: $36-42$.

Metera, E., Sakowski, T., Słoniewski, K. \& Romanowicz, B. 2010: Grazing as a tool to maintain biodiversity of grassland - a review. Animal Science Papers and Reports 28: 315-334.

Moioli, B., Georgoudis, A., Napolitano, F., Catillo, G,. Giubilei, E., Ligda, Ch. \& Hassanane, M. 2001: Genetic diversity between Italian, Greek and Egyptian buffalo populations. Livestock Production Science 70: 203-211.

Napolitano, F., Grasso, F., Saltalamacchia, F., Martiniello, P., Bilancione, A., Pacelli, C. \& De Rosa G. 2007: Grazing behaviour of buffalo heifers. Italian Journal of Animal Science 6: 1256-1259.

Napolitano, F., Pacelli, C., Grasso, F., Braghieri, A. \& De Rosa, G. 2013: The behaviour and welfare of buffaloes (Bubalus bubalis) in modern dairy enterprises. Animal 7 (10): 1704-1713.

National Statistical Service of Greece 1960: Agricultural Statistics of Greece. Athens, Greece [In Greek].

Papanastasis, V. P., Yiakoulaki, M. D., Decandia, M. \& DiniPapanastasi, O. 2008: Integrating woody species into livestock feeding in the Mediterranean areas of Europe. Animal Feed Science Technology 140: 1-17.

Reinhart, V. 1985: Studying the behavior or the American buffalo. Buffalo! 13: 23. 
Ryan, S.J. \& Jordaan, W. 2005: Activity patterns of African buffalo Syncerus caffer in the Lower Sabie Region, Kruger National Park, South Africa. Koedoe 48: 117-124.

Schultz, E., Schultz, T.A., Garmendia, J. C. \& Chico, C. F. 1977: Comparison of cattle and domestic buffaloes fed on tropical forage at three vegetative stages. 1 . Behaviour, intake and rumination. Agronomie Tropicale 27: 319-330.

Schlecht, E., Hiernaux, P., Kadaoure, I., Hulsebusch, C. \& Mahler, F. 2006: A spatio-temporal analysis of forage availability and grazing and excretion behaviour of herded and free grazing cattle, sheep and goats in Western Niger. Agriculture, Ecosystems \& Environment 113: 226-242.

Sutcliffe, L. M. E., Batáry, P., Kormann, U., Báldi, A., Dicks, L. V., Herzon, I., Kleijn, D., Tryjanowski, P., Apostolova, I., Arlettaz, R., Aunins, A., Aviron, A., Baležentiene, L., Čierna-Plassmann, M., Fischer, C., Gabrielová, J., Halada, L., Hartel, T., Helm, A., Hristov, I., Jelaska, S. D., Kaligarič, M., Kamp, J., Klimek, S., Koorberg, P., Kovács-Hostyánszki, A., Kuemmerle, T., Leuschner, C., Lindborg, R., Loos, J., Maccherini, S., Marja, R., Máthé, O., Proença, V., ReyBenayas, J., Sans, F. X., Seifert, C., Stalenga, J., Timaeus, J., Török, P., van Swaay, C., Viik, E. \& Tscharntke, T. 2015: Harnessing the biodiversity value of Central and Eastern European farmland. Diversity \& Distributions 21: 722-730.

Török, P., Valkó, O., Deák, B., Kelemen, A. \& Tóthmérész B. 2014: Traditional cattle grazing in a mosaic alkali landscape: Effects on grassland biodiversity along a moisture gradient. PlosONE 9: (5) Paper e97095.
Török, P., Valkó, O., Deák, B., Kelemen, A., Tóth, E. \& Tóthmérész B. 2016: Managing for species composition or diversity? Pastoral and free grazing systems of alkali grasslands. Agriculture, Ecosystems \& Environment. DOI: 10.1016/j.agee.2016.01.010

Tsiobani, E., Yiakoulaki, M., Hasanagas, N. \& Papanikolaou, K. 2013: Pluriactivity and professionalism in buffalo (Bubalus bubalis) farming system: The case of Northern Greece. Indian Journal of Animal Sciences 83: 763-767.

Tsiobani, E. T., Yiakoulaki, M. D., Hasanagas, N. D. \& Papanikolaou, K. Ch. 2014. Water buffaloes' diet selection grazing at the area of the Lake Kerkini, Northern Greece. Journal of Mountain Agriculture on the Balkans 17 (1): 30-40.

Yiakoulaki, M., Tsiobani, E., Evangelou, Chr. \& Hasanagas, N. 2015. Grasslands in danger of overgrazing: The case of the Lake Kerkini. In: Proceedings of the $17^{\text {th }}$ National Forestry Conference. 4-7 October 2015. Kefalonia, Greece. pp. 513-518 [In Greek].

Wiegleb, G. \& Krawczynski, R. 2010: Biodiversity Management by Water Buffalos in Restored Wetlands. Waldökologie, Landschaftsforschung und Naturschutz 10: 17-22. 